IIUC STUDIES

ISSN 1813-7733

Vol.- 7, December 2010

(Published in December 2011) (p 91-106)

\title{
The Advent of Islam in Bengal; An Economic Perspective
}

\author{
Md. Thowhidul Islam*
}

\begin{abstract}
This article aims at examining the causes to the advent of Islam in Bengal with a view to identify the economic perspectives in particular. Islam took about six hundred years for its advent into Bengal with political conquest by Bakhtiyar Khalji in the early $13^{\text {th }}$ century, while it had come to Arabia at the beginning of the $7^{\text {th }}$ century. But long before the conquest of Bengal by Bakhtiyar Khalji, the Arab traders had established commercial relation with the coastal lands of Bengal. Islam began to enter into Bengal with the hands of these early Arab Muslim traders. With the beginning of this early advent, Islam started to enter into Bengal through both the sea and land routes on different circumstances. Though there were many other reasons and grounds for the advent of Islam in Bengal, but the economic perspectives were the foremost and forerunner of the causes.
\end{abstract}

\section{Introduction}

The religion of Islam began to enter into the Indian Sub-Continent within one hundred years of its advent in the early $7^{\text {th }}$ century in Arabian Peninsula through the Prophet Mohammad (SAW). Primarily it started with the conquest of Sind and Multan in the early $8^{\text {th }}$ century by an Arab lieutenant of Hajjaj bin Yusuf, the viceroy of eastern provinces of the Umayyad Caliphate, Muhammad bin Qashim. Though this conquest did not leave a permanent rule of the Muslims in the Sub-Continent, but left only religio-cultural impact on the people of Indus Valley. Moreover, the wave of this conquest could not penetrate deep into the heart of the Sub-Continent, not to speak of her eastern regions like Bengal. ${ }^{\text {i }}$ It took about five hundred years for Muslim

\footnotetext{
${ }^{*}$ Lecturer in Bangladesh Studies, Center for University Requirement Courses (CENURC), IIUC
} 
political power to reach Bengal, when Bakhtiyar Khalji brought Bengal under the control of the Muslim rule in the early $13^{\text {th }}$ century defeating the Sena king Lakhsman Sena. Really it is difficult to identify the exact year of the advent of Islam in Bengal due to the paucity of historical evidences. Most of the modern historians considered the year of 1204 A.D. as the year of Bakhtiyar Khalji's victory over Bengal. ${ }^{\text {ii }}$ According to unconfirmed traditions, some Muslim Sufi-saints came to Bengal even before the political conquest. But it may be said with historical information and analysis that the Arab traders came earlier into the Sub-Continent as well as Bengal and founded the basis of commercial contact between the two lands which opened the gateway for the advent of Islam in Bengal. We will try to give an analysis in this paper about the early contact between Bengal and Arabia with a view to identify particularly the economic background and perspectives for the advent of Islam in Bengal.

\section{Early Arab Muslims' Economic Contact with Bengal through the Waterways:}

The commercial relation of Indian Sub-Continent particularly of Bengal with Arab world was established between the merchants of the two parts probably soon after 2800 B.C. From historic times in Mesopotamia Indian cotton was known by the name of Sindhu, and it passed into Greece in the form of Sindon. During the period between the decline of the Greeco-Roman trade with Indian Sub-Continent in the third century A.D., a number of important political changes took place affecting Indo-Arab trade relation, and causing the transfer of the traffic into the hands of the Persians. In the century before the rise of Islam, the Persians were supreme in the Arabian Sea trade. Their boats frequented the harbours of India. Sea-going ships from India sailed as far as Al-Madain up to the Tigris, and Al-'Ubulla had been termed as Arj al-Hind, ${ }^{\text {iii }}$ the marches of India. However, after the advent of Islam the Arabs re-established their control over the sea trade.

Islam entered into Bengal both by land and water routes. By land, the Turkish conquerors came first with the religion of Islam and their culture at the time of Bakhtiyar's invasion into Bengal, while the Arab traders came through the waterways. Long before the Turkish conquest, Early Arab Muslims had established commercial contact with the coastal lands of Indian Sub-Continent including Bengal. From the very beginning, the Arab Muslims were trade oriented nation due to the lack of agricultural facilities in Arabian Peninsula as most of the Arab lands were desert. They were the foremost seafaring and 
maritime people of the then world. They carried on extensive maritime trade between the Eastern Asian countries and the western European nations. From geographical study, it is quite clear that even before the advent of Islam, Arab regions played an important role as a bridge between the trade of East and West through the sea routes of Mediterranean Sea, Red Sea and Persian Gulf. After the advent of Islam, the Arab Muslims established absolute control over these sea routes including Arab Sea, Indian Ocean till to the Pacific. The Western Mediterranean having become a Muslim lake. ${ }^{\text {iv }}$ Arab dominance over the trade routes of sea became a reality in the 10th century. There were major settlements of Arab traders scattered along the west and south coast of Indian Sub-Continent and Sri Lanka, with similar facilities extending into the chain of Islands at the South China Sea and the Philippines. Indeed so dominant and pervasive was Arab traders control of this trade route, that the Europeans were driven to despair trying to work out how to carve out profitable routes for themselves. K. A. Nizami wrote as follows;

India's relations with the Arab world go back to hoary past. Long before the rise of Islam, there was brisk commercial contact between India and Arabia and the Arab traders carried Indian goods to the European markets by way of Egypt and Syria. Elphinstone has rightly observed that from the days of Joshep to the days of Marco Polo and Vasco de Gama the Arabs were the captains of Indian commerce. There were large number of Arab colonies on the western coast of India and many Indian settlements in the Arab countries.... When Islam spread and the Arabs got converted to Islam, these colonies continued to flourish as before. The Indian Rajas appointed Muslim judges, known as hunurman, to decide their cases and provided all facilities to them to organise their community life. Commercial contact led to cultural relations and while large number of Arab navigational and other terms were adopted by the Indians, Indian customs, institutions and practices found their way to Arabia. Philologists have traced three Sanskrit words misk (Musk), zanbil (ginger) and kafur (camphor) - in the Quran. ${ }^{\mathrm{v}}$ 
Thus the coastal areas of India including Bengal turned into the important commercial centres of world trade, where the Arab traders had to stay in the midway to the South-East Asian countries till to the Far East of China. In course of time, they extended their commercial activities to the entire coastal regions of south Asia including Bengal, Burma, Malaysia, Indonesia and as far as China. So the Indian and Bengal coastal regions were as a transition zone between the trade of west and the Far East of China. ${ }^{\mathrm{vi}}$ As is well known, the piratical capture of some Arab vessels, while coming from Ceylon, off the coast of Debal of Sind led to the conquest of Sind in 712 A.D. led by Muhammad bin Qashim. It not only secured the Arab navigation but also encouraged and gave an impetus to their commercial activities on the entire sea routes. Unfortunately we have no detail of the early contact between Arabia and Bengal. Some indirect references are found in the writings of Arab Geographers, which may be identified with some places in Eastern India in general and Bengal in particular. Sulaiman wrote in his Silsiltu-T Tawarikh in this connection;

These three states border on a kingdom called Ruhmi, which is at war with that of Jurz. The king is not held in very high estimation. He is at war with the Balhara as he is with the king of Jurz. His troops are more numerous than those of the Balhara, the king of Jurz or the king of Tafak. It is said that when he goes out to battle, he is followed by about 50,000 elephants... It is stated that there are from ten to fifteen thousand men in his army who are employed in fulling and washing clothes. There is a stuff made in his country which is not to be found elsewhere; so fine and delicate is this material that a dress made of it may be passed through a signet-ring. It is made of cotton, and we have seen a piece of it. Trade is carried on by means of Kauris, which are the current money of the country. They have gold and silver in the country."vii

Modern scholars have tried to identify the kingdom of Ruhmi of Sulaiman's description. According to Hodivala the kingdom of Ruhmi may be identified with the kingdom of Dharmapala in Bengal (770-

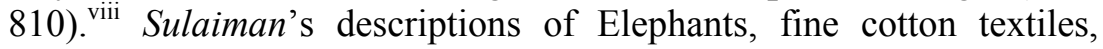
Cowrie as the medium of exchange suggest that the reference was to Bengal. Because of all later writers as Minhaj, Ibn Batuta and almost all European travelers gave similar information about Bengal. Masudi 
said "The kingdom of Rahma extends both along the sea and the continent. It is bounded by inland state called the kingdom of Kaman." Kaman is a variant form of Kamrup and so the kingdom of Rahma may be identified as Bengal. Ibn Khurdadbih said that Jazirat al-Rami comes after Sarandip and contains peculiar unicorn animals and little naked people. ${ }^{\mathrm{x}}$ Yaqut identified it as the farthest land of India towards the Strait of Malacca. ${ }^{\mathrm{xi}}$ All these descriptions indicate the location of Rami or Rahma off the coast between the Bay of Bengal and the straits of Malacca. We know that Ramu or Rame was a state on the eastern coast of the Bay of Bengal comprising some districts of Chittagong, now which is a small town of Cox's Bazar district of Bangladesh. The English traveler Ralph Fitch who visited Bengal in 1585-86, also referred to the kingdom of Rame. ${ }^{\text {xii }}$ So it may be assumed that the Jazirat al-Rami of Arab Geographers was the state of Rami (now Ramu) on Chittagong coast.

Ubaidullah Ibn Khurdadhbih while discussing the places of trade interest on the coast of Indian Ocean after "Sarandip" (Ceylon) and the river "Kudafarid" (Godavari on the East Indian coast) referred to a port called "Samandar" where rice was produced and to which aloewood was brought down for export from a distance of 15 or 20 days through sweet water from a territory named Kamrun. ${ }^{\text {iii }}$ Al-Idrisi also mentioned the port of Samandar as follows:

"Samandar is a large town, commercial and rich, where there are good profits to be made. It is a town dependent upon Kanauj, king of this country. It stands upon a river which comes from the country of Kashmir. Rice and various grains, especially excellent wheat, are to be obtained here. Aloe wood is brought hither from the country of Kamrut (Kamrup) 15 days distance, by river of which the waters are sweet. The aloe-wood which comes from this country is of a superior quality and of a delicious perfume. It grows in the mountains of Karan. One day's sail from this city there is a large island well peopled and frequented by merchants of all countries. It is four days distance from the island of Sarandip. To the north at seven days distance from Samandar, is the city of Kashmir the inner, celebrated throughout India: which is under the rule of Kanauj. From Kashmir to Kamrut four days. From Kashmir to Kanauj about seven days. This is 
a fine commercial city which gives the name to the king of the country."xiv

From the above description of Arab geographers, it is clear that the port of Samandar is located just after the East Indian coast. Ibn Khurdadbih particularly mentioned that it is after the river Godavari towards the east, which indicates to be the Bengal coastal regions. Both of Ibn Khurdadbih and Al Idrisi spoke about the abundance production of rice, which is till now the chief agricultural production of south-eastern part of Bengal. The aloe-wood was exported from Kamrut or Kamrun, which is modified form of Kamrup, a district of Assam. In ancient times it was applied to a wider area. ${ }^{\mathrm{xv}}$ This hilly region was famous for producing enough aloe-wood. ${ }^{\text {xvi }}$ The rivers of Brahmaputra and the Jamuna passing through Assam, joined near Dhaka and with the river Ganges or Padma near Goalandaghat and these combined stream along with the Meghna fallen into the Bay of Bengal. This was evidently the "sweet water" route of Arab Geographers, which was used in exporting aloe-wood. According to Al-Idrisi's statement Samandar is situated in an inlet on the bank of a large river. There is no other mentionable inlet on the whole coastline from Ceylon to Burma where a large river falls except south-eastern part of Bengal through which the combined stream of three rivers the Ganges (Padma), the Brahmaputra (Jamuna) and the Meghna fallen into the Bay of Bengal. The statement also suggests that the river on the mouth of which Samandar located, came from the land of Kashmir. The river Ganges or now Padma in Bangladesh only the river came from Gangotri glacier of Himalayan Mountains which is very close to Kashmir. The rivers of Ganges and the Brahmaputra coming from Himalayan Mountains met together at Goalandaghat of Rajbari district of Bangladesh and this combined streams of two rivers met with the Meghna at Chandpur and fallen into the Bay of Bengal in the name of the Meghna which formed the only navigable inlet between Ceylon and Burma. The statement "dependent upon Kanauj, king of this country" refers to another point. Originally Kanauj is a city of North-India, which was brought under the sway of the kingdom of Dharmapala (752-832) of Bengal. Probably for that imperial tradition Al-Idrisi gave this relative statement. According to his statement there is an island one day's distance from Samandar and four day's from Sarandib (Ceylon). It obviously refers to the island of Sandhwip which located at the mouth of the rivers of Ganges (Padma), the Brahmaputra (Jamuna) and the Meghna to the Bay of Bengal. It was a large and flourishing commercial centre. ${ }^{\text {xii }}$ So the port of 
Samandar is situated at the near of the island of Sandhwip. Dr. Abdul Karim identified Samandar as the port of Chittagong ${ }^{\text {xviii }}$ and $D r . M$. Mohar Ali tried to identify it as present Chandpur. ${ }^{\text {xix }}$ Whatever Chittagong or Chandpur, Samandar was obviously identified as a port of Bengal.

From the above description of Arab geographers we may evidently conclude that there was a strong relation between Arab and the coastal lands of Bengal and this relation was purely commercial based on the trade of export and import. The Arab traders built up this relation only for trading interest. They exported and imported various delicious and valuable items as rice, sugar, aloe-wood, medicinal-wood whose leaves produced bitter juice, cotton cloths such as Muslin (very fine cotton garments), ivory, rhino horns and otter skins, horses, perfumes, spices, Persian luxurious items and many other commodities from and to Indian territories along with Bengal, South-Asian countries including Far East of China, Arabia, Egypt, Syria, Persia, and many other European countries.

\section{Archeological evidences:}

This early commercial relation between Arabia and Bengal is evidently supported by local archeological discoveries. Archeologists have discovered three silver coins; one at the ancient Buddhist site at Paharpur in Nowgaon district of north Bengal in 1937-38, which belonged to the great Abbasid Caliph Harun al-Rashid (786-809) and dated on 788 A.D. ${ }^{\mathrm{xx}}$ Two others were found at the ruin of Mainamoti in Comilla district. ${ }^{\mathrm{xxi}}$ Though the proper identification of the second two coins is difficult for want of information, it seems that these also belonged to the Abbasid period. It is assumed that these coins brought here by the Arab traders in the $8^{\text {th }}$ or $9^{\text {th }}$ century. So the presence of Arab coins in the deep inland of Bengal proved the presence of Arab traders as the coins generally bear the trading identity. The Arab traders might be reached at Comilla or Paharpur through the rivers of Meghna and Padma from the coast of Eastern Bengal. Recently a mosque of 69 A.H. has been discovered at the village of Ara of Panchagram union in the district of Lalmonirhat. ${ }^{\text {xxii }}$ According to the findings, it was established 8 years after the incident of Karbala and 24 years before the expedition of Muhammad bin Qashim in Sind. On the discovered bricks there was mentioned the year of 69 Hijri with the Kalima-i-Tayyibah (the first Muslim creed). Though it is hitherto under the consideration for recognition of the archeologists, if it is approved as historical evidence, this will also witness the presence of 
Islam along with considerable number of Muslim settlement in North Bengal. Basing on these archeological evidences we may conclude that the Early Arab Muslims had a strong commercial relation with Bengal prior to the Muslim political conquest by the Turks.

\section{Early Arab Muslim Settlement and Local Traditions:}

The Arab traders in course of their trade, settled down in Malabar, Ceylon, Java, Sumatra, Malaya and other places on their trade routes. So it is assumed that some of them might have settled in the fertile coastal lands of Bengal as it was prosperous with various valuable commodities as Cotton, Spices, and Woods in particular. Though the question of this early Arab settlement is hitherto an issue of discussion among the scholars, some of them tried to prove Arab Muslim rule in the north Bengal in the $8^{\text {th }}$ century. ${ }^{\text {xxiii }}$ Enamul Haq explained that the Arab Muslim settlers in Chittagong region had gradually grown to be a compact and influential community and had in course of time organised an independent principality of their own comprising the coastal belt of Chittagong and Noakhali Districts, and that the ruler of this Muslim principality bore the title of Sultan. ${ }^{\text {xiv }}$ His explanation was based on some Arakani chronicles. In such a chronicle King Tsula-Taing Tsan-da-ya (951-957) defeated one Thu-ra-tan and erected a victory memorial at a place Tset-ta-going (Chittagong). ${ }^{\mathrm{xxv}}$ According to him, Thu-ra-tan is an Arakani form of Arabic word Sultan which is used as a title for the ruler. M. A. Rahim also supported this explanation and said that "Surtan is an Arakenese corruption of Sultan." $x x v i$ Doubts also expressed about the possibility of such early Arab settlement before the military conquest. ${ }^{\text {xxvii }}$ Besides this Arakani anecdote, the geographical location of Chittagong also favoured the theory of early Arab settlement as it is situated at the eastern end of the Gulf formed at the mouth of the combined flow of three major rivers the Ganges, the Brahmaputra and the Meghna. The great admixture of Arabic words and phrases in the local dialect of Chittagong also supports the theory of Early Arab settlement. Moreover, the name of Chittagong is also an Arabic origin. Probably the Arab merchants called it as Shat-al-Gangha in Arabic with meaning the valley or the bank of Gangha. This expression gradually changed into the local form of Chatgaon which Ibn Batuta called Sadkawan ${ }^{\text {xxviii }}$ and finally formed into Chittagong. A large number of the vocabularies of local language of Chittagong are either pure Arabic or derived from Arabic root. The influence of Arabic language on the dialect of Chittagong also may be a curious research issue. The names of many places and people bear Arabic influence. Many social customs also preserve the 
Arabic tradition. This deep Arabicization of locality is only the result of long and constant intercourse with a sizable group of Arab residents in the locality. ${ }^{\text {xxix }}$ The later visitors as Barbosa of Portugal (1518) also found the port city with inhabited mainly by the Arab Muslims and others who conducted prosperous trade with other parts of South East Asian coastal territories as Coromondol, Malabor, Cambay, Pegu, Sumatra, Malacca, Ceylon etc. ${ }^{\mathrm{xx}}$ The principal factor behind such settlement was mainly to secure their trade and ensure the supply of trading commodities. It was necessary for the Arab big merchants to have settled down some of their agents nearer to the ports or trade centres to supervise their business, provide security, ensure supply and maintain communication between Arab merchants and local traders. Sometimes natural calamities also caused shipwrecks and compelled the survivors to seek shelter in the near by coastal lands. An Arakani chronicle mentioned that few Arabs after a shipwreck off the coast of Arakan were settled by the king Ma-ba-toing (780-810). ${ }^{\mathrm{xxxi}}$

The social condition of the then Bengal was also favourable to such an early Arab Muslim settlement. The Sena Rulers in Bengal had originally come from south-India and established in Bengal by suppressing the local Buddhist Pala rulers. They also installed an orthodox Hinduism with strict caste system and the Satti system. ${ }^{\text {xxxii }}$ There were about nearly hundred castes and sub-castes existed in the society among which social interactions were prohibited. ${ }^{\text {xxiii }}$ The lower classes of Hindus had been oppressed by the upper classes. They neither inter-marry nor inter-dine. They had no right to change their professions. Moreover, the lower classes of Hindus had no permission to enter into the city. The Buddhism was also corrupted. Buddhism had, for a variety of reasons, declined and many of its ideas and forms had been adsorbed into Hinduism. The Hinduization of the simple teachings of Gautama was reflected in the elevation of the Buddha into a divine being surrounded, in sculptural representations, by the gods of the Hindu pantheon. The Buddha later came to be shown as an incarnation of Vishnu. ${ }^{\text {xxiv }}$ Moreover the Buddhists also were lived under the constant oppression of the Sena Rulers. M. N. Roy described the social background to the expansion of Islam more beautifully as follows:

Evidently, society was in such a disintegrated and chaotic state as to make the position even of the most privileged class insecure. That is usually the result of counter revolution. A revolution may be defeated by a 
combination of forces; but that does not enable the triumphant forces of reaction to remove the causes of social disintegration which brought about the revolution. In India, the Buddhist revolution was not defeated; it was miscarried owing to its internal weakness. Social forces were not sufficiently mature to carry the revolution to victory. Consequently, after the downfall of Buddhism, the country found itself in a worse state of economic ruin, political oppression, intellectual anarchy and spiritual chaos. Practically, the entire society was involved in that tragic process of decay and decomposition. That is why not only the oppressed masses readily rallied under the banner of Islam which offered them social equality if not political equality; even the upper classes offered their services to the foreign aggressor out of selfish motives. That shows that, while the masses were in a state of despire, the upper classes were thoroughly demoralised.....In any case, it is clear that at the time of Mohammedan conquest, there lived in India multitudes of people who had little reason to be faithful to Hindu laws and the traditions of Brahmans orthodoxy, and were ready to forsake that heritage for the more equitable laws of Islam which offered them protection against the tyranny of triumphant Hindu reaction. $^{\mathrm{xxxv}}$

So the social equality among the Muslims impressed the local people of Bengal. Sometimes Arab Muslim traders received local reverted girls as their wives. The Satti system and the Prohibition of widow marriage remained in the Hindu society while widow marriage was encouraged and Satti system was prohibited in Islam. Being influenced by these social equity, justice and simplicity of Islam, the Hindus and Buddhists, lower classes of Hindus in particular showed respect to the Arab Muslims and gradually reverted and flocked into the fold of Islam with their hands. ${ }^{\text {xxxi }}$ Finding this congenial atmosphere for their faith as well as trade, the Arab Muslim traders were also influenced to be settled here. On the other hand, the Arab traders were also largely attracted to the natural beauty of Bengal as they had come from a desert land. After the advent of Islam, one of the attractive characteristics of the then Arabs was that they carried on the new message of Islam whenever and wherever they went. So the Arab 
traders and settlers also carried on with them the new message of Islam to the inhabitants of the coastal lands of Bengal. But their professional and prime objective was the security and extension of trade with other places and countries.

\section{Advent of Islam in Bengal through the land routes:}

The regions of the Indian Sub-Continent came in contact with Islam by land when Mohammad bin Qashim made expedition and conquered Sind in 712 A.D. during the time of Umayyad Caliph Al-Walid. The main cause which led to this expedition was the piratical capture of some Arab vessels off the coast of Debal in Sind full of valuable gifts sent by the ruler of Ceylon to the Umayyad Caliph al-Walid and Hajjaj ibn Yousuf, the governor of eastern provinces. Though the rule of Mohammad bin Qashim was not lasted for long time over the conquered land, but it had left a significant impact on the people of India by introducing a new faith and culture to this land. It primarily opened the door for gradual expansion of Islam in Indian SubContinent. Though the wave of this conquest could not reach Bengal, to some extent the wind of this change also touched the territories of Bengal as a part of the Sub-Continent. But considerable matter is that it was purely an economic attempt. Secondly, Mahmud, the Sultan of Gazni (997-1030) was the remarkable figure in the history of India in making a direct land contact of Islam with the Sub-Continent of India. Historians are not clear concerning either the exact number or the dates of Sultan Mahmud's expeditions. The general belief is that he made seventeen expeditions between the years 1000 to 1026 A.D. but he did not establish a permanent rule over the conquered territories though he got victory in every expedition. The causes and motives of his campaigns have too often been misrepresented. Some historians called him as a raider-in-chief while others as a great propagator of Islam. But after a brief discussion, the modern historians identified that the real causes behind his expeditions were political and economic. In order to build-up the newly founded empire of Ghazni, to establish authority in his kingdom and his superiority over the kings of Islamic world, to finance his magnificent schemes in arts and culture, and to provide sufficient emolument to the mercenaries who, unless and until they were given enough reward for their services, would not have accompanied him to his distant expeditions, he stood in need of money and India was a veritable source of wealth. So Sultan Mahmud invaded India several times and returned to his kingdom with valuable wealth. Thus he did not need to found an everlasting kingdom in India. Through these politico-economic invasions, the lands of India 
including Bengal came into direct contact with the people who belonged to the faith of Islam. Indeed it left a significant impact on the people of the Sub-Continent and also many Hindus accepted Islam. Needless to say that it included Bengal as it was a part of the SubContinent. Thirdly, The Indian sub-continent came under the direct rule of the Muslims, when Muhammad Ghuri launched a vigorous expedition against Pritwiraj, the leader of Rajput, in the second battle of Tarain in 1192 A.D. ${ }^{\text {xxvii }}$ This battle may be regarded as the decisive contest which ensured the ultimate success of the Muslims in India. After this victory Qutubuddin Aibek, who belonged to the viceroyalty of Muhammad Ghuri in India, captured Delhi, the capital in 1193 and gradually conquered many other territories of the Sub-Continent. He founded the Independent Delhi Sultanate in 1206 A.D. after the death of Muhammad Ghuri. Simultaneously with Qutubuddin's conquest, Ikhtiaruddin Muhammad Bakhtiyar Khalji, a young man accompanied Muhammad Ghuri to India, captured Bihar, the fortified monastery of Buddhists defeating the shave-headed monks possessing wealth and books, then known as Magadha in 1202-03 A.D. ${ }^{\text {xxviii }}$ This conquest opened the whole territory upto Bengal before Bakhtiyar Khalji. The Sena king Lakhsman Sena was the then ruler of Bengal with one of his capitals at Nadia ${ }^{x x x i x}$ of west Bengal. In the next year 1204 A.D., ${ }^{\mathrm{xl}}$ Bakhtiyar Khalji marched towards Nadia and captured Bengal. Originally, Bakhtiyar Khalji was a fortune seeker, who being refused to join in the army of Qutubuddin Aibek, went to Oudh and got jagirdaries (landed estate) of two parganas or villages (bhuili and Bhagwat) in the south-east corner of Mirzapur district under Malik Husam al-Din. His aim till then was to invade the neighbouring states in order to capture their treasures and to raise his own army with the adventurous Khalji Amirs, who came to India in search of better fortunes. Soon he gathered strength by bringing a band of adventurous Turks, his countrymen, under his command and gradually conquered neighbouring territories as well Bengal. So the principal aim of Bakhtiyar's expedition was to build up a kingdom for economic prosperity. On the other hand, the commercial relation between Bengal and Arabia was so deep that when Bakhtiyar reached at the entrance of Nadia palace with only 18 horsemen, the people guarding the gates took them as the Muslim horse traders and therefore did not oppose their entry into the city. ${ }^{\text {xli }}$ This shows that the people from Arabia and other Muslim countries used to come to the inside cities of Bengal for trading concern long before the expedition of Bakhtiyar. So the trade 
contact paved the way of religio-political victory of the Muslims in Bengal.

It may be noted that in course of this commercial contact and political advancement, a good number of Sufi-saints or religious preachers also entered into Bengal who propagated the religious ideology of Islam among the inhabitants. Most prominent among these early Sufi-saints in Bengal were Baba Adam Shahid of Munsiganj district, ${ }^{\text {xlii }}$ Shah Mohammad Sultan Rumi of Madanpur, Netrakona, ${ }^{\text {xliii Shah Sultan }}$ Mahisawar of Mahastangarh in Bogra district, ${ }^{\text {xliv }}$ and Makhdum Shah Daula Shahid of Shabazpur in Pabna district. ${ }^{\text {xlv }}$ It is very difficult to ascertain the exact dates of their arrival, but from the contemporary sources the modern historians identified their arrival in Bengal before the military expedition. ${ }^{\text {xlvi }}$

\section{Concluding Remarks:}

From the above discussion, we may summerise that Arabia had a strong commercial contact with the coastal lands of Indian SubContinent including Bengal long before the advent of Islam. After the advent of Islam, the Arab Muslims established their trading and political supreme control over the sea routes which included western Mediterranean Sea, Persian Gulf, Red Sea, Arabian Sea, and Indian Ocean till to the Pacific. So they extended their trade contact which reached to the inland of Bengal and sometimes they married the local girls and settled here to ensure the trading supply and security. One of the distinguished characteristics of the then Arab Muslims was that, whenever and wherever they went, they carried on the new message of Islam. So the Arab traders also came to Bengal with the new ideological message of Islam. As the local socio-cultural condition of the then Bengal was also in favour of the expansion of new faith, being influenced by the social equality and justice among the Muslim traders, many lower classes of Hindus and Buddhists reverted to Islamic faith. On the other hand, the military expeditions and land conquests by the Muslim army, also caused mainly by several commercial factors than the others. Though many religious preachers, Sufi-saints came to the Sub-Continent to preach Islam and most of the conversions happened through the hands of those saints, but it must be admitted that the commercial and trading causes were largely contributed to the advent and expansion of Islam in Bengal. So the economic perspectives were the pioneer to the religio-political advent of Islam in Bengal. 


\section{Notes and References}

i Karim, Abdul, Social History of the Muslims in Bengal, (Chittagong, 1985), p. -1.

ii Chowdhury, A. M., Dynastic History of Bengal, (Dhaka, 1967), pp.252-258.

iii Nizami, K. A., in the introduction of the Book "Arab Accounts of India" edited by Dr. Mohammad Zaki, (Delhi, 2009).

iv Pirenne, Henry, Mohammad and Charlemagne, (London, 1986), p. 285.

$\mathbf{v} \quad$ Nizami, K. A., op. cit.

vi See Hourani, George Faldo, Arab Seafaring in the Indian Ocean in Ancient and Medieval Times, (Princeton University Press, 1951).

vii Elliot and Dowson, History of India as told by its own Historians, vol. 1, (London, 1867), p.-5.

viii Hodivala, S. H., Studies in Indo-Muslim History, (Bombay, 1939), p. -4.

ix Elliot and Dowson, op. cit., p.-25

x Khurdadbih, Ibn, Kitab al-Masalik wal-Mamalik, (E.J. Brill, 1889), p. - 65.

xi Yaqut, Mu'jam al-Buldan, (Beirut edition, 1957), vol.-3, p.-18.

xii Purchas, S., Hakluytus Posthumas or Purchas His pilgrims, vol.-10, (Glasgow, 1906), p.-183

xiii Khurdadbih, Ibn, op. cit., pp.-63-64.

xiv Al-Idrisi, Nuzhat al-Mushtaq, extract translated in Elliot, Arab geographers, pp. - 90-91.

$\mathbf{x v}$ Kamrup was mentioned as a frontier state on the east of the Gupta Empire in Samudragupta's Allahabad Pillar Inscription $\left(4^{\text {th }}\right.$ century A.D.). See Fleet, Corpus Inscriptionum Indicarum, Vol.-3, (Gupta Inscriptiops).

xvi Fadl, Abul, Ain-i-Akbari, translated by Sarkar, (Calcutta, 1877), Vol.-2, p.-187.

xvii Sarkar, J.N. (edited), History of Bengal, Voll-2, (Dacca University, 1948), p.-360. See also J.A. Campos, The Portuguese in Bengal, (Calcutta, 1919).

xviii Karim, Abdul, op. cit., pp. -31-33. 
xix Ali, Mohar M., History of the Muslims of Bengal, Vol-I A, (Imam Muhammad Ibn Sa'ud Islamic University, 1985), pp. -33-34.

xx Dikshit, K.N., Memories of the Archeological Survey of India, No. 55, (Delhi, 1938), p. -87.

xxi Khan, F.A., Recent Archeological Discoveries in East Pakistan: Mainamati, (Pakistan publications, Karachi, n.d.), p.- 11.

xxii The Daily Bangla, 23 ${ }^{\text {rd }}$ April of 1986 titled "Hijri 69 Soner Mosjid Abishkar".

xxiii Ali, Mehrab, Eksha Teish Hijrir Shilalipi (Inscription of 123 A.H.), Dinajpur Museum Series No. 4.

xxiv Haq, Muhammad, Enamul, Purba Pakistane Islam Prochar, (Dacca, 1948), p. -17. also see Arakan Rajsabhaya Bangala Sahitya, (ed. By Enamul Haq and Abdul karim, Calcutta, 1935), p.-13.

$\mathbf{x x v}$ Journal of the Asiatic Society of Bengal, 1844, Vol. - 13, p. - 36.

xxvi Rahim, M. A., Social and Cultural History of Bengal, Vol. -1, (12011576), (Karachi, 1963), p. - 44

xxvii See A. H. Dani, "Early Muslim Contact with Bengal”, The proceedings of the Pakistan History Conference, Karachi session, 1951.

xxviii Gibb, H.A.R., Ibn Batuta, (London, 1929), p. - 267.

xxix Haq, Muhammad, Enamul, Purba Pakistane Islam Prochar, (Dacca, 1948), p. -19 .

xxx Purchas, S., Hakluytus Posthumas or Purchas His pilgrims, Vol.-1, (Glasgow, 1906), pp. - 144-145.

xxxi Journal of the Asiatic Society of Bengal, 1844, Vol. - 13, p.-36.

xxxii According to the Satti system, Hindu widows would go to burn with her dead husband.

xxxiii For details about caste system in Bengal, see R.C. Majumdar (edited), History of Bengal, Vol.-1, (The University of Dacca, 1976), pp. - 565-593.

xxxiv Edwards, Micle, A History of India, (1967), p. - 29.

xxxv Roy, M. N., The Historical Role of Islam, (Delhi, 1981), pp. - 82-84.

xxxvi Khan, Mohammad, Akram, Moslem Bhonger Samajik Itihash, (Dacca, 1965), p. -83 .

xxxvii Majumdar, R.C. (edited), History and Culture of the people of India, Vol. - 5 (The struggle for empire), (Bombay, 1957), pp. - 110-111. 
xxxviii Basak, R.G., quoting Gayakara Misra's Manuscript, in Proceedings of the Indian History Congress, 1939, p.- $531 \mathrm{ff}$, and Dr. D.C. Sircar, quoting the Luckeeserai Inscription, J.A.S.B. Vol.- 18, 1951, No. - 1, p. -29 .

xxxix Lakhsman Sena had two capitals at Bikrampur of East Bengal and Nadia of West Bengal. Bikrampur was the main capital, while Nadia was a seasonal palace for the king.

xl There has been some disagreement among the scholars about the exact date of Bakhtiar's expedition to Nadia. Charles Stewart fixed the date on the basis of contemporary Persian sources as 1203-04 A.D. (History of Bengal, $2^{\text {nd }}$ edition, 1910, pp.-16). Edward Thomas agreed with Stewart and gave the date 1202-03 (The Chronicle of the Pathan Kings of Delhi, pp. -110). Minhajal-Din-Siraj categorically tells that the conquest took place in the second year of Bakhtiyar's visit with Qutubuddin Aibek at Badayun in 1203 A.D. (Tabaqat I Nasiri, tr. by Elliot and Dowson, Vol.-2, p.-307.), while Dr. A.H. Dani concluded by fixing the correct date as 1204 A.D. (Indian Historical Quarterly, 1954, pp. 133-147).

xli Minhajal-Din-Siraj, Tabaqat-I- Nasiri, tr. by Elliot and Dowson, (Calcutta, 1880), Vol. - 2, p.-557.

xlii For tradition regarding him see the Journal of the Asiatic Society of Bengal, 1889, Vol. - 57, pp.-12-19.

xliii Haq, Muhammad, Enamul, Bange Sufi Probhav, (Calcutta, 1935), p. -138.

xliv For tradition regarding him see the Journal of the Asiatic Society of Bengal, 1875, part-1, No.-2, pp.-183-186.

xlv For tradition regarding him see the Journal of the Asiatic Society of Bengal, 1904, part-1, No.-3, pp.-262-271. Also Bengal District Gazetteers; Pabna, 1923, pp. $121-136$.

xlvi For details about the Sufi-saints in Bengal see Karim,Abdul, op. cit., pp. -115-187, and also Rahim, M. A., Social and Cultural History of Bengal, tr. Into Bengali by Asaduzzaman, M. (Bangla Academy, Part-1, Dhaka, 2008), pp. - 54-116. 